\title{
Community Leadership: A Theory-Based Model
}

\author{
Kevan W. Lamm, Ph.D. \\ President \\ LR Brand, Inc. \\ Hannah S. Carter, Ph.D. \\ Associate Professor Department of Agricultural Education and Communication, Director \\ Wedgworth Leadership Institute for Agriculture and Natural Resources \\ University of Florida

\begin{abstract}
Alexa J. Lamm, Ph.D.
Assistant Professor Department of Agricultural Education and Communication, Associate Director UF/IFAS Center for Public Issues Education University of Florida
\end{abstract} \\ Angie B. Lindsey, Ph.D. \\ Assistant Professor Department of Family, Youth, and Community Sciences \\ University of Florida
}

\begin{abstract}
The community is one of the foundations of our modern society. Community represents an important context that is unique from other leadership settings. Although there are an abundance of context agnostic theories and models within the leadership literature, a theoretically-based model specifically intended for community leadership remains notably absent. The purpose of this article was to address this gap by proposing a theoretically-based model of community leadership. The proposed model expands upon previous recommendations in the literature and specifically identifies 20 areas within five superordinate factors. The community leadership conceptual model should provide leadership educators with a robust framework for developing contextually appropriate leadership curriculum.
\end{abstract}

\section{Introduction}

The community is one of the foundations of our modern society (Putnam, 2001). It is the theoretical, or physical, space that binds individuals together and is inextricably linked with the concept of social capital (Sander \& Putnam, 2010). According to Sander and Putnam (2010), social capital relates to "social networks and the norms of reciprocity and trust to which those networks give rise. No democracy, and indeed no society, can be healthy without at least a modicum of this resource" (p. 9). The importance of community as an important concept, and context, is well established (Rogers, 2003; Wilkinson, 1991).

There are an abundance of theories and models within the leadership literature that focus on more generally acknowledged leadership contexts (e.g. Fleishman et al., 1991); however, a theoretically-based model specifically intended for community leadership remains notably absent 
(Kirk \& Shutte, 2004; Pigg, 1999). Based on the importance of community, the absence is both noteworthy and troubling (Pigg, 1999). Contextually specific leadership models have been shown to result in more effective and consistent leadership outcomes (Bass, 2008).

Community development is one of the most productive ways to improve the lives and livelihoods of individuals within a community (Syme \& Ritterman, 2009). Community leaders have been shown to be an effective mechanism to support and enable community development in the past (Kirk \& Shutte, 2004). Therefore, a theoretically-based model of community leadership should aid not only community leaders directly, but also secondary recipients within the community that benefit from development activities (Barker, Johnson, \& Lavalette, 2001). Developing a context specific model for community leadership is consistent with recommendations from the literature which have recommended, "the field of leadership education needs to develop standardized leadership curriculum” (Brungardt, 2011, p. 16).

Leadership classification systems have been shown to be an effective approach to providing contextually appropriate leadership models (Bass, 2008). For example, an interpersonal leadership conceptual model developed by Lamm, Carter, and Lamm (2016) organized 24 unique leadership dimensions into three superordinate factors, specifically: entry conditions, core functions, and sub-themes. The proposed model is consistent with, but not redundant with, other proposed leadership models (Bass, 2008; Fleishman et al., 1991; Yukl, Gordon, \& Taber, 2002). A leadership classification system specifically developed to address community leadership could provide similar clarity for a community leadership context (Pigg, 1999).

Based on the National Leadership Education Research Agenda 2013 - 2018 priority area one, leadership education should "explore curriculum development frameworks to enhance the leadership education transfer of learning" (Andenoro et al., 2013, p. 5). Accordingly, this article presents a theoretically-derived conceptual model of community leadership based on a comprehensive review and synthesis of the existing leadership literature. The resulting model should provide an appropriate curriculum framework to enhance the transfer of learning in leadership education settings.

\section{Community Leadership}

Community has been defined as "a process of interrelated actions through which residents express their common interest in the local society" (Wilkinson, 1991, p. 2); from this perspective, the structure of what constitutes a community has been considered somewhat of a paradox relative to organizations (Pigg, 1999). Specifically, organizations and communities, as defined, are both constructed through psychological bonds (e.g. Katz \& Kahn, 1977); however, community typically entails a physical space, or bond, as well (Pigg, 1999).

One of the challenges for leaders within communities has been that some do not have any sort of formal authority associated with positional power (O'Brien \& Hassinger, 1992). Rather, "they must rely on networks and influence, with relationships developed through extensive interactions with community residents usually representing many different points of view or interests" (Pigg, 1999, p. 196). 
Accordingly, community leadership has similar characteristics with opinion leadership proposed by Lazarsfeld, Berelson, and Gaudet (1948). Whereby leaders influence their networks and contacts, although they may not have any formal leadership role. However, a differentiator between opinion and community leaders has been that the challenges for community leaders have been confounded by what constitutes a community, which "cuts across social fields that comprise it, integrating them by creating and maintaining the linkages among the specialinterest organizations and associations" (Pigg, 1999, p. 198).

Nevertheless, despite the challenges that have been associated with defining the domain, the underlying function of community leaders has been consistent with more organizationally based models of leadership; specifically, that leadership has been required to mobilize the resources necessary to achieve a common goal or set of goals (Pigg, 1999). However, the means and methods that have been associated with effective community leadership remain a significant limitation within the existing literature (O’Brien \& Hassinger, 1992).

Initiation and spread of interest. Unlike organizational leadership that has tended to rely on positional power, and subsequently attributed leadership to those positions (e.g. Robbins \& Judge, 2014), leadership from a community perspective has tended to be more emergent (Wilkinson, 1991). Specifically, leadership opportunities have generally been initiated when an issue has been identified; leaders have tended to emerge through the initiation and spread of interest around an issue (Pigg, 1999; Wilkinson, 1991).

Effective community leaders have been characterized as change agents (Schein, 1995); individuals with the ability to mobilize others (Javidan \& Dstmalchian, 1993), createconditions (McGrath, 1964), and take the initiative (Winter, 1978). A recurrent theme within the literature has been that such leaders have clarity about their purpose (Larson \& LaFasto, 1989).

Additionally, community leaders tend to share other characteristic similarities. Specifically, effective leaders tend to have a sense of service (e.g. Craig \& Gustafson, 1998; Van Wart, 2003) and accountability (Van Dierendonck \& Nuijten, 2011). Leaders have also been found to be highly participative (House \& Mitchell, 1974), and have been shown to take on a symbolic role for the group (e.g. Birnbaum, 1988). Furthermore, an implicit attribution of leadership (Lord \& Maher, 1991) has been found to be more readily made to individuals that behave ethically (Liden, Wayne, Zhao, \& Henderson, 2008) and morally (Sendjaya, Sarros, \& Santora, 2008) with an evident set of values (e.g. George, 2003).

Within a community structure the issue, and creation of awareness, have been found tobe paramount (Pigg, 1999). Leaders must have a purpose (Pigg, 1999). For example, community leaders have been found to innovate and challenge existing processes (e.g. Kouzes \& Posner, 2002). Through the process of identifying a purpose, effective leaders have been found to make decisions (e.g. Luthans \& Lockwood, 1984) and define their goals (e.g. Bass, 1981; House, 1977; Podsakoff, MacKenzie, Moorman, \& Fetter, 1990).

After a leader has established their purpose and goal, a subsequent step associated with spreading interest has been communication. An ability to disseminate information within a community has been identified as a critical set of activities (e.g. Israel, Schulz, Parker, \& Becker, 
1998; Metcalfe, 1984). Effective leaders have been shown to employ numerous, and appropriate, communication strategies (e.g. Jacobs, 1983). For example, leaders have been shown to use their ability to network and interface with other members of the community as a means to create awareness (Senge, 1995). An intended outcome associated with the communication process has been to motivate others within the community (e.g. Kouzes \& Posner, 2002). An informed, interested, and motivated community has been found to be critical in a leader's ability to fulfill their purpose (Pigg, 1999).

Organization of sponsorship. When a satisfactory level of awareness has been established, community leaders have been shown to move their efforts into an involvement and participation phase, or establishing an organization of sponsorship (Pigg, 1999; Wilkinson, 1991). According to the literature, one of the most critical first steps has been to appropriately plan and organize (e.g. Page, 1985; Yukl, 1998). In so doing, leaders have been found to provide order (Wilson et al., 1990), clarity and structure (Bass \& Farrow, 1977).

Subsequent to sufficient planning, leaders have been found to build a coalition of community members or organizations (e.g. Hahn, Greene, \& Waterman, 1994). A leader's ability to establish relationship has been found to be paramount (Pigg, 1999). Leaders have been found to utilize their reputation (Bell, Hill, \& Wright, 1961) and resources (Terry, 1993) to stimulate further involvement and participation.

Throughout the organizing process, leaders have been shown to actively facilitate cooperation and teamwork (Yukl \& Nemeroff, 1979). Frequently, a leader's ability to encourage cohesiveness (Bonjean \& Olson, 1964) has been derived though their awareness (e.g. Greenleaf, 1970 ) and ability to exchange information amongst constituent members (Luthans \& Lockwood, 1984).

According to the literature, effective leaders also tend to be sensitive to conditions and respond accordingly. For example, leaders have been found to have an ability to align the purpose of the group to the environment (e.g. Van Wart, 2003) and provide direction accordingly (Senge, 1995). Additionally, leaders have tended to have a tolerance for uncertainty (Stogdill, Goode, \& Day, 1965) while maintaining their ability to be aware of time considerations (Wilson, O'Hare, \& Shipper, 1990).

Goal setting and strategy formulation. Based on a successful effort to increase involvement and participation, community leaders have been shown to move into a decision making phase, specifically, setting goals and formulating a strategy (Pigg, 1999; Wilkinson, 1991). Although a community leader may have emerged to address an issue, their purpose has been shown to become shared, and sometimes modified, based on their interaction with other members of the community (Pigg, 1999).

According to the literature, goal setting (Van Fleet \& Yukl, 1986) and pressure (Wilson et al., 1990) have been associated with higher levels performance. Furthermore, appropriate goals have been shown to influence a leader's ability to solve the problems of the community (e.g. Mumford, Zaccaro, Harding, Jacobs, \& Fleishman, 2000). To be an effective problem solver (Yukl, Wall, \& Lepsinger, 1990) leaders have been found to be adaptable (e.g. Heifetz, 
1994) and resilient (Luthans \& Avolio, 2003). Unlike other forms of leadership where a leader can mandate the pursuit of a particular outcome, community leadership has been found torequire more goal flexibility on the part of the leader (Pigg, 1999).

One of the intended outcomes associated with a resonant goal, has been the development of a shared vision (e.g. Conger \& Kanungo, 1998; Dennis \& Bocarnea, 2005). An ability to harness their conceptual skills (Liden et al., 2008) and provide meaningful insights (Greenleaf, 1970) has also been associated with developing a vision.

As part of the decision-making phase, leaders have been shown to define a strategy. In particular, the ability to propose procedures (Metcalfe, 1984) and establish standards (Larson \& LaFasto, 1989) intended to result in the shared vision has been associated with effective leadership. Throughout the process, leaders have been found to use their own experience (e.g. Mumford et al., 2000) and knowledge (e.g. Barbuto \& Wheeler, 2006) to propose the appropriate strategy; however, high performing leaders have also been found to encourage others to participate in the decision-making process (Yukl \& Nemeroff, 1979).

As on ongoing process of involvement and consensus building, effective leaders have been shown to validate proposals amongst members. Specifically, leaders have been shown to establish collaborative environments (Israel et al., 1998) that encourage participation (Metcalfe, 1984). The orientation towards more collective processes has also been identified within the literature (e.g. Hofstede, 1980; House, Hanges, Javidan, Dorfman, \& Gupta, 2004). A leader's willingness to collectively process and monitor the environment for potential changes (Van Fleet \& Yukl, 1986) has been associated with loyalty of the leader to their members (Velasquez, 1992), and ultimately more acceptance and focus on accomplishing goals through a mutually agreeable strategy (Pigg, 1999).

Recruitment. After a goal has been set and a strategy has been agreed, community leaders have been found to move into a resource mobilization, or recruitment, phase (Pigg, 1999, Wilkinson, 1991). Effective leaders have been shown to initiate recruitment through interaction and inspiring others. For example, leaders attend to the needs of others (e.g. Bass \& Avolio, 1990) through empathy (Greenleaf, 1970) and consideration (e.g. Stogdill et al., 1965).

Furthermore, leaders have been found to help members connect to the goal and strategy (Kirk \& Shutte, 2004) by inspiring a shared vision (e.g. Kouzes \& Posner, 2002) and establishing a common mission (Terry, 1993). Through intentional interaction (Bennett, 1971) effective leaders have been shown to build upon the strengths of the membership (Gupta \& Govindarajan, 1984; Metcalfe, 1984).

In an effort to most effectively mobilize resources, leaders have been found to support and enable their members. Specifically, leaders have been shown to provide coaching (e.g. Hersey \& Blanchard, 1969), training (e.g. Luthans \& Lockwood, 1984), mentoring (Yukl, 1998), and developmental opportunities (Laub, 1999; Van Wart, 2003). Additionally, high performing leaders have also been shown to provide ongoing support for their members as necessary (e.g. Yukl et al., 1990). 
A prominent theme within the literature has been that leaders also empower their members. Through delegating (e.g. Hersey \& Blanchard, 1969) and sharing leadership (Laub, 1999), leaders have been shown to empower others (e.g. Liden et al., 2008). When leaders stand back (Van Dierendonck \& Nuijten, 2011) and enable others to act (Kouzes \& Posner, 2002) they have created co-learning environments (Israel et al., 1998) where the collective has been empowered (Kirk \& Shutte, 2004). Furthermore, when leaders have understood the needs of others (e.g. Mumford et al., 2000) and attended to their morale (Helme, 1974) they have been better able to recognize the community as a unit of identity (Israel et al., 1998).

An ability to coordinate resources has also been associated with effectiveleadership (Kraut, Pedigo, McKenna, Dunnette, 1989). Unlike organizational settings where personnel might be managed more directly (e.g. Prien, 1963), effective community leaders have been shown to have a higher tolerance for member freedom (Stogdill et al., 1965). Acting as a representative of the group (e.g. Yukl \& Nemeroff, 1979) rather than a positional leader has been associated with effective community leadership when recruiting and mobilizing resources (Pigg, 1999).

Implementation of strategy and plans. Once resources have been mobilized, community leaders have been found to move into a final phase where resources are applied, specifically through the implementation of the strategy and plans (Pigg, 1999; Wilkinson, 1991). According to the literature, leaders have been found to gain a final consensus prior to implementation of plans. Specifically, leaders have acted as coordinators (e.g. Page, 1985) based on their ability to act as stewards for the membership (e.g. Greenleaf, 1970; Van Dierendonck \& Nuijten, 2011). Additionally, leaders have been shown to facilitate consensus building within the membership by developing a level of trust within the group (Dennis \& Bocarnea, 2005), combined with their ability to build a sense of community (e.g. Laub, 1999) and being sensitive to the politics associated with the membership (Beckhard, 1995).

After consensus has been adequately achieved, leaders have been found to move into an implementation stage. In particular, leaders have combined informing (e.g. Yukl, 1998) and communication (Jacobs, 1983) to facilitate the implementation of strategies and plans (Farr, 1982). Additionally, leaders have been found to be appropriately directive (House \& Mitchell, 1974) throughout the process to provide a stabilizing force (Jacobs, 1983).

Although the process of pursuing a goal within a community leadership paradigm has been found to be unique based on the reliance on membership and shared decision making (O'Brien \& Hassinger, 1992), effective leaders have been shown to be consistently focused on monitoring the goal and taking the steps necessary to ensure success (Wilkinson, 1991). For example, leaders have been shown to be committed to the ongoing success of the membership (Whitehead, 2009). Commitment has been demonstrated through a leader's defense of the group's integrity (Selznick, 1957) as well as their willingness to engage in feedback (Wilsonet al., 1990), perform critical analysis of outcomes (Van Fleet \& Yukl, 1986), and manage conflicts within the membership (Craig \& Gustafson, 1998). Additionally, effective leaders have been shown to be sensitive to external environmental influences (Mumford et al., 2000) to ensure the ongoing implementation success of the membership's strategy and plans (Pigg, 1999). 


\section{Community Leadership Conceptual Model}

Based on the review of existing literature, a theory-based conceptual model of community leadership has been provided (Figure 1). The model synthesizes the previous leadership factors identified within the literature. Furthermore, the model is structured in accordance with recommendations associated with previous attempts to develop leadership frameworks or models (e.g. Bass, 2008). Specifically, the model expands upon the five primary activities to task accomplishment as proposed by Pigg (1999): initiation and spread of interest, organization of sponsorship, goal setting and strategy formulation, recruitment, and implementation of strategy and plans. The items proposed under each activity heading are based on consistent themes identified within the literature when considered from a community leadership perspective (Bass, 2008).

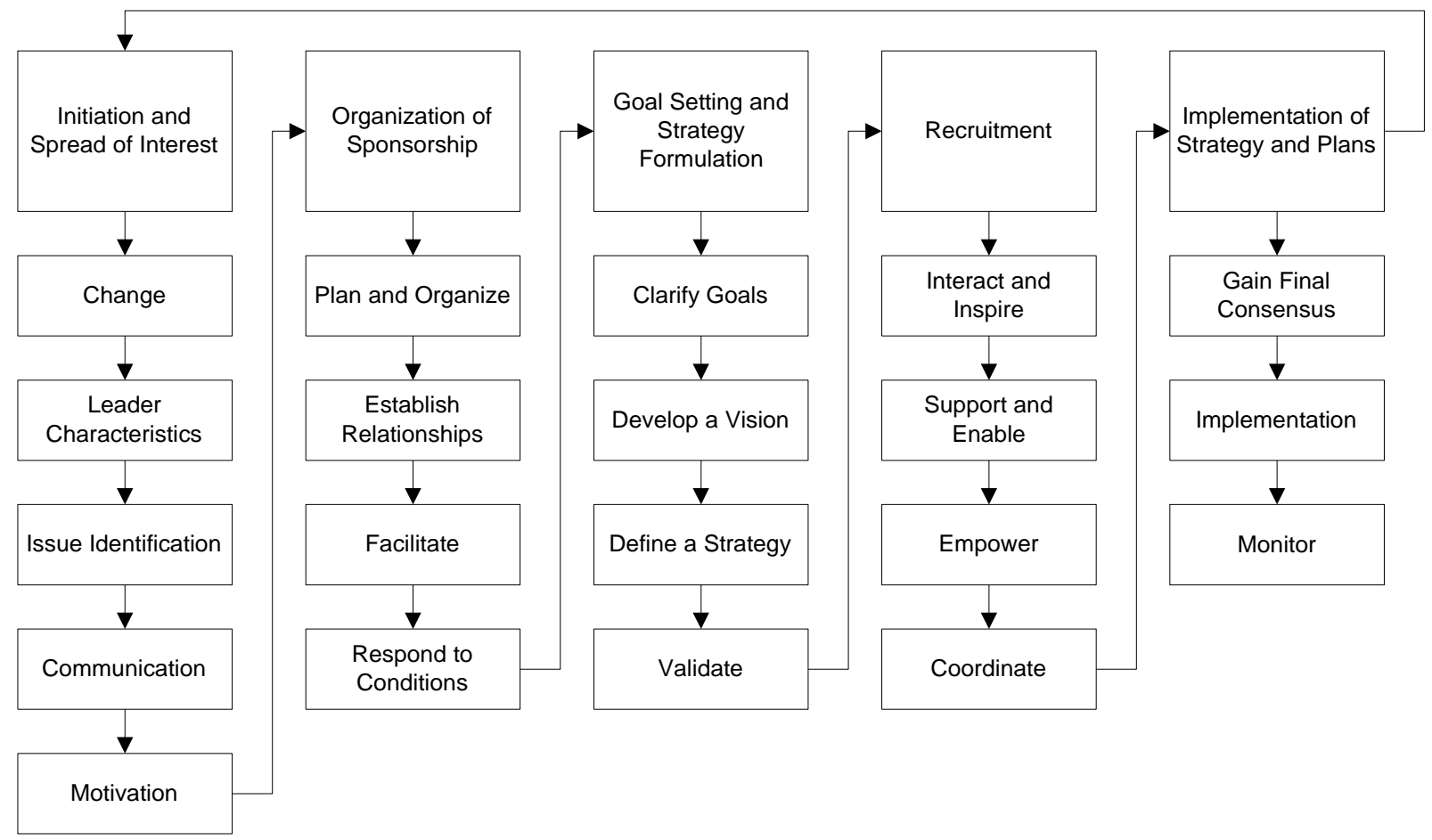

Figure 1. Conceptual model of community leadership

Within a community setting, the initial phase, initiation and spread of interest, has included multiple sub-steps (Wilkenson, 1991). Specifically, a leader must first identify anissue, and then must act as a change agent to address the issue (e.g. Schein, 1995). Additionally, community leaders tend to share other characteristic similarities such as a sense of service (e.g. Craig \& Gustafson, 1998; Van Wart, 2003). Next, leaders clearly identify the issue and goals (e.g. Kouzes \& Posner, 2002), then go about communicating and disseminating information regarding the issue within the community (e.g. Israel et al., 1998). Motivating members of the 
community to become interested in the issue has been identified as an outcome of the communication process (e.g. Kouzes \& Posner, 2002).

Community leaders then move into an involvement and participation phase by establishing an organization of sponsorship (Pigg, 1999; Wilkinson, 1991). This process has included taking the time to plan and organize (Page, 1985; Yukl, 1998). A subsequent step has included establishing relationships (Pigg, 1999) and then facilitating cooperation and teamwork (Yukl \& Nemeroff, 1979). Additionally, leaders have been found to respond to evolving conditions throughout the process (Van Wart, 2003).

Following efforts to increase involvement and participation, leaders tend to set goals and formulate a strategy (Pigg, 1999; Wilkinson, 1991). First, leaders have been found to clarify goals with the membership (Van Fleet \& Yukl, 1986). As an outcome of the process the leader works in coordination with the membership to develop a vision for the intended outcome (e.g. Conger \& Kanungo, 1998; Dennis \& Bocarnea, 2005). Using the vision as a guide, leaders then have worked to define a strategy for achieving the vision (e.g. Mumford et al., 2000). Lastly, effective leaders have also been shown to validate proposals amongst members (Israel et al., 1998).

After goal setting and strategy formulation, leaders have been shown to move into a resource mobilization, or recruitment, phase (Pigg, 1999, Wilkinson, 1991). Specifically, leaders have been shown to initiate recruitment through interaction and inspiring others (e.g. Bass \& Avolio, 1990; Greenleaf, 1970). Next, leaders have been found to support and enable their members (e.g. Hersey \& Blanchard, 1969, Luthans \& Lockwood, 1984). When sufficiently enabled, effective leaders have been found to empower others (Liden et al., 2008) and to coordinate activities and actions of the membership accordingly (Kraut et al., 1989).

A final phase in the process has been identified as the implementation of the strategy and plans (Pigg, 1999; Wilkinson, 1991). Leaders have been shown to gain a final consensus prior to implementation of plans (Page, 1985), followed by moving forward with implementation (Farr, 1982). Lastly, leaders have been found to continue to monitor the success of the implementation over time (Whitehead, 2009).

\section{Conclusion}

The importance of community, and the value associated with community development, are well established from both a practical and theoretical perspective (Putnam, 2001; Syme \& Ritterman, 2009). Generally, leadership models have presumed a formal position of authority to accompany leadership roles (Bass, 2008); however, community leadership is a context where this presumption is not applicable (Pigg, 1999). Previous research has proposed a general community leadership process (Pigg, 1999); however, the existing model lacked depth and structure necessary for developing viable leadership curriculum (Brungardt, 2011).

The purpose of this research was to develop a theoretically-grounded conceptual model of community leadership. The proposed model integrated the previously established community leadership process with a synthesis of the most relevant themes from the existing leadership 
literature (Bass, 2008; Fleishman et al., 1991; Yukl, Gordon, \& Taber, 2002). The outcome is a conceptual model of community leadership appropriate for establishing standardized community leadership curriculum (Brungardt, 2011).

Based on similarities between opinion leadership (Lazarsfeld et al., 1948) and the proposed community leadership model, a recommended next step would be to focus on the influence aspects of community leadership. Positional authority is not a pre-requisite for either community leadership or opinion leadership, therefore overlapping concepts should be used to reinforce the importance of influence over authority. Leadership educators are also recommended to focus on the need for community leaders to remain connected and aware of the communities they are intending to serve. Previous research with opinion leaders has found that knowledge, or awareness, gaps may develop that may limit the efficacy of leadership efforts (Lamm, Lamm, \& Carter, 2015).

In addition to making the logical connections between opinion leadership and community leadership, leadership educators are recommended to employ, or adapt, the proposed model to support leadership curriculum development, specifically directed at community leadership development. The model should provide a robust framework; however, application and experiences should provide more engaging learning opportunities bringing in real world experience (Kolb, 1984) and acknowledging the needs of adult learners.

Future theoretically-based models of leadership linked to specific contexts are also recommended. Additional models may provide options to supplement existing models that tend to be context agnostic. Education, including leadership education, should be contextually appropriate, and leadership development curriculum should be created to address a specific context when appropriate (McKeachie \& Svinicki, 2011). A diverse set of leadership development curriculum frameworks should provide leadership educators with options to use when enhancing the leadership education process (Andenoro et al., 2013). 


\section{References}

Andenoro, A. C., Allen, S. J., Haber-Curran, P., Jenkins, D. M., Sowcik, M., Dugan, J. P., \& Osteen, L. (2013). National Leadership Education research agenda 2013-2018: Providing strategic direction for the field of leadership education. Retrieved from Association of Leadership Educators website: http://leadershipeducators.org/ ResearchAgenda.

Barbuto Jr., J. E., \& Wheeler, D. W. (2006). Scale development and construct clarification of servant leadership. Group and Organizational Management, 31(300), 326.

Barker, C., Johnson, A., \& Lavalette, M. (2001). Leadership and social movements. Manchester University Press.

Bass, B. M. (1981). Bass and Stogdill's handbook of leadership. New York: The Free press.

Bass, B. M. (2008). The bass handbook of leadership. New York, NY: Free Press.

Bass, B. M., \& Avolio, B. J. (1990). Transformational leadership development: Manual for the multifactor leadership questionnaire. Palo Alto, CA: Consulting Psychologists Press.

Bass, B. M., \& Farrow, D. L. (1977). Quantitative analyses of biographies of political figures. Journal of Psychology, 97, 281-296.

Beckhard, R. (1995). On future leaders. In F. Hesselbein, M. Goldsmith \& R. Beckhard (Eds.), The leader of the future. San Francisco: Jossey-Bass.

Bell, W., Hill, R. J., \& Wright, C. R. (1961). Public leadership: A critical review with special reference to adult education. San Francisco: Chandler.

Bennett, E. B. (1971). Discussion, decisions, commitment, and consensus in "group decision". Human Relations, 8, 251-273.

Birnbaum, R. (1988). Responsibility without authority: The impossible job of the college president. New York: National Center for Postsecondary Governance andFinance, Teachers College, Columbia University.

Bonjean, C. M., \& Olson, D. M. (1964). Community Leadership: directions of research. Administrative Science Quarterly. 9(3). 278-300.

Brungardt, C. (2011). The intersection of soft skill development and leadership education. Journal of Leadership Education. 10(1). 1-22.

Conger, J. A., \& Kanungo, R. (1998). Charismatic leadership in organizations. Thousand Oaks, CA: Sage Publications. 
Craig, S. B., \& Gustafson, S. B. (1998). Perceived leader integrity scale: An instrument for assessing employee perceptions of leader integrity. Leadership Quarterly, 9, 127-145.

Dennis, R. S., \& Bocarnea, M. (2005). Development of the servant leadership assessment instrument. Leadership \& Organization Development Journal, 26, 600-615.

Farr, J. L. (1982). A five-factor system of leadership. Greensboro, NC: Farr Associates.

Fleishman, E. A., Mumford, M. D., Zaccaro, S. J., Levin, K. Y., Korotkin, A. L., \& Hein, M.B. (1992). Taxonomic efforts in the description of leader behavior: A synthesis and functional interpretation. The Leadership Quarterly, 2(4), 245-287.

George, B. (2003). Authentic leadership: Rediscovering the secrets to creating lasting value. San Francisco: Jossey-Bass.

Gupta, A. K., \& Govindarajan, V. (1984). Build, hold, harvest: Converting strategic intentions into reality. The Journal of Business Strategy, 4(3),34-47.

Greenleaf, R. K. (1970). The servant as leader. Indianapolis, IN: Robert K. GreenleafCenter.

Hahn, A. J., Greene, J. C., \& Waterman, C. C. (1994). Educating about public issues lessons from eleven innovative public policy education projects. Ithaca, Ny: Cornell Cooperative Extension.

Heifetz, R. (1994). Leadership without easy answers. Cambridge, MA: Harvard University Press.

Helme, W. H. (1974). Leadership research findings applied to the officer personnel management system. Alexandria, VA: U.S. Army Research Institute.

Hersey, P., \& Blanchard, K. H. (1969). Management of organizational behavior. Englewood Cliffs, NJ: Prentice-Hall.

Hofstede, G. (1980). Culture's consequences: International differences in work related values. Beverly Hills, CA: Sage.

House, R. J. (1977). A 1976 theory of charismatic leadership. In J. G. Hunt, \& L. L. Larson (Eds.), Leadership: The cutting edge. Carbondale, IL: Southern Illinois University Press.

House, R. J., Hanges, P. J., Javidan, M., Dorfman, P. W., \& Gupta, V. (2004). Culture, leadership, and organizations: The GLOBE study of 62 societies. Thousand Oaks, CA: Sage.

House, R. J., \& Mitchell, T. R. (1974). Path-goal theory of leadership. Journal of Contemporary Business, 3, 81-97. 
Israel, B. A., Schulz, A. J., Parker, E. A., \& Becker, A. B. (1998). Review of community-based research: Assessing partnership approaches to improve public health. Annual Review of Public Health, 19, 173-202.

Jacobs, O. (1983). Leadership requirements for the air land battle. Paper Presented at the Leadership on the Future Battle Field Symposium, Texas Tech University, Lubbock, TX.

Javidan, M., \& Dastmalchian, A. (1993). Assessing senior executives: The impact of context on their roles. The Journal of Applied Behavioral Science, 29, 289-305.

Katz, D., \& Kahn, R. L. (1977). The social psychology of organizations. New York: Wiley.

Kirk, P., \& Shutte, A. M. (2004). Community leadership development. Community Development Journal, 39(3), 234-251. doi:10.1093/cdj/bsh019

Kolb, D. A. (1984). Experiential learning: Experience as the source of learning and development. Upper Saddle River, New Jersey: Prentice Hall.

Kouzes, J. M., \& Posner, B. Z. (2002). The leadership challenge (3rd ed.). San Francisco: Jossey-Bass.

Kraut, A. I., Pedigo, P. R., McKenna, D. D., \& Dunnette, M. D. (1989). The role of the manager: What's really important in different management jobs. Academy of Management Executive, 3, 286-293.

Lamm, K. W., Carter, H. S., Lamm, A. J. (2016). A theory based model of interpersonal leadership: an integration of the literature. Journal of Leadership Education, 15(4), 183205. doi: 1012806/V15/I4/T2.

Lamm, K. W., Lamm, A. J., \& Carter, H. S. (2015). Bridging water issue knowledge gaps between the general public and opinion leaders. Journal of Agricultural Education, 56(3), 146-161.

Larson, C. E., \& LaFasto, F. M. J. (1989). Teamwork: What must go right; what can go wrong. Newbury Park, CA: Sage.

Laub, J. A. (1999). Assessing the servant organization: Development of the servant organizational leadership assessment (SOLA) instrument (Ed.D.). Available from ProQuest Dissertations \& Theses Full Text. (304517144). Retrieved from http://search.proquest.com/docview/304517144?accountid=10920

Lazarsfeld, P., Berelson, B., \& Gaudet, H. (Eds.). (1948). The people's choice (2nd ed. ed.). New York: Columbia University Press. 
Liden, R. C., Wayne, S. J., Zhao, H., \& Henderson, D. (2008). Servant leadership: Development of a multidimensional measure and multi-level assessment. Leadership Quarterly, 19, 161-177.

Lord, R. G., \& Maher, K. J. (1991). Leadership and information processing: Linking perceptions and performance. Boston: Unwin Hyman.

Luthans, F., \& Avolio, B. J. (2003). Authentic leadership development. In K. S. Cameron, J.E. Dutton \& R. E. Quinn (Eds.), Positive organizational scholarship (pp. 241-258). San Francisco: Berrett-Koehler.

Luthans, F., \& Lockwood, D. L. (1984). Toward an observation system for measuring leader behavior in natural settings. In J. G. Hunt, D. Hosking, C. A. Schriesheim \& R. Stewart (Eds.), Leaders and managers: International perspectives on managerial behavior and leadership (pp. 117-141). New York: Pergamon Press.

McKeachie, W., \& Svinicki, M. (2013). McKeachie’s teaching tips. Cengage Learning.

McGrath, J. E. (1964). Leadership behavior: Some requirements for leadership training. Office of Career Development, U.S. Civil Service Commission.

Metcalfe, B. A. (1984). Microskills of leadership: A detailed analysis of the behaviors of managers in the appraisal interview. In J. G. Junt, D. M. Hosking, C. A. Schriesheim \& R. Stewart (Eds.), Leaders and managers: International perspectives on managerial behavior and leadership. New York: Permagon Press.

Mumford, M. D., Zaccaro, S. J., Harding, F. D., Jacobs, T. O., \& Fleishman, E. A. (2000). Leadership skills for a changing world: Solving complex social problems. The Leadership Quarterly, 11(1), 11-35.

Northouse, P. G. (2013). Leadership: Theory and practice (6th ed.). Thousand Oaks: Sage Publications.

O'Brien, D. J., \& Hassinger, E. W. (1992). Community attachment among leaders in five rural Communities. Rural Sociology, 57(4), 521-534.

Page, R. (1985). The position description questionnaire. Minneapolis, MN: Control Data Business Advisors.

Pigg, K. E. (1999). Community leadership and community theory: A practical synthesis. Journal of Community Development Society, 30(2), 196-212.

Podsakoff, P. M., MacKenzie, S. B., Moorman, R. H., \& Fetter, R. (1990). Transformational leader behaviors and their effects on followers' trust in leader, satisfaction, and organizational citizenship behaviors. The Leadership Quarterly, 1(2), 107-142. doi:10.1016/1048-9843(90)90009-7 
Prien, E. P. (1963). Development of a supervisor position description questionnaire. Journal of Applied Psychology, 47(1), 10-14.

Putnam, R. D. (2001). Bowling alone: The collapse and revival of American community. Simon and Schuster.

Robbins, S. P., \& Judge, T. (2014). Organizational behavior (16th ed.). Upper Saddle River, N.J: Pearson Prentice Hall.

Rogers, E. M. (2003). Diffusion of innovations (5th ed.). New York, NY: Free Press.

Sander, T. H., \& Putnam, R. D. (2010). Still bowling alone?: The post-9/11 split. Journal of Democracy, 21(1), 9-16.

Schein, E. (1995). Organizational and managerial culture as a facilitator or inhibitor of organizational transformation. (No. Working Paper 3831). Cambridge, MA: MIT Sloan School of Management.

Selznick, P. (1957). Leadership in administration: A sociological interpretation. Evanston, IL: Row \& Peterson.

Sendjaya, S., Sarros, J. C., \& Santora, J. C. (2008). Defining and measuring servant leadership behaviour in organizations. Journal of Management Studies, 45(2), 402-424.

Senge, P. M. (1995). Reflection of leadership: How Robert K. Greenleaf's theory of servantleadership influenced today's top management thinkers. Robert Greenleaf's legacy: A new foundation for twenty-first century institutions (pp. 217-240). New York, NY: John Wiley and Sons.

Stogdill, R. M., Goode, O. S., \& Day, D. R. (1965). The leader behavior of university presidents. Columbus, OH: Ohio State University, Bureau of Business Research.

Syme, S. L., \& Ritterman, M. L. (2009). The importance of community development for health and well-being. Community Development Investment Review, 5(3), 1-13.

Terry, R. W. (1993). Authentic leadership: Courage in action. San Francisco: Jossey-Bass.

Van Dierendonck, D., \& Nuijten, I. (2011). The servant leadership survey: Development and validation of a multidimensional measure. Journal of Business and Psychology, 26(3), 249-267.

Van Fleet, D. D., \& Yukl, G. A. (1986). Military leadership: An organizational behavior perspective. Greenwich, CT: JAI Press. 
Van Wart, M. (2003). Public-sector leadership theory: An assessment. Public Administration Review, 63(2), 214-228.

Velasquez, M. G. (1992). Business ethics: Concepts and cases (3rd ed.). Englewood Cliffs, NJ: Prentice Hall.

Wilkinson, K. P. (1991). The community in rural America. New York: Greenwood Publishing Group.

Whitehead, G. (2009). Adolescent leadership development building a case for an authenticity framework. Educational Management Administration \& Leadership, 37(6), 847-872.

Wilson, C. L., O'Hare, D., \& Shipper, F. (1990). Task cycle theory: The processes of influence. In K. E. Clark, \& M. B. Clark (Eds.), Measures of leadership (pp. 185-204). West Orange, NJ: Leadership Library of America.

Winter, D. G. (1978). Navy leadership and management competencies: Convergence among tests, interviews, and performance ratings. Boston, MA: McBer \& Company.

Yukl, G. (1998). Leadership in organizations (4th ed.). Englewood Cliffs, NJ: Prentice-Hall.

Yukl, G., Gordon, A., \& Taber, T. (2002). A hierarchical taxonomy of leadership behavior: Integrating a half century of behavior research. Journal of Leadership \& Organizational Studies, 9(1), 15-32.

Yukl, G. A., \& Nemeroff, W. (1979). Identification and measurement of specific categories of leadership behavior: A progress report. In J. G. Hunt, \& L. L. Larson (Eds.), Crosscurrents in leadership (pp. 164-200). Carbondale, IL: Southern Illinois University Press.

Yukl, G., Wall, S., \& Lepsinger, R. (1990). Preliminary report on validation of the managerial practices survey. In K. E. Clark, \& M. B. Clark (Eds.), Measures of leadership (pp. 223238). West Orange, NJ: Leadership Library of America. 


\section{Author Biographies}

Kevan Lamm, Ph.D., is the president of LR Brand, Inc. a private consulting firm specializing in evaluation, operational execution, and talent development. kevan.lamm@gmail.com

Hannah Carter, Ph.D., is an associate professor of leadership education in the Department of Agricultural Education and Communication at the University of Florida. Within this appointment, she is the Director of the Wedgworth Leadership Institute for Agriculture and Natural Resources and also the interim director for the UF/IFAS Center for Leadership. hscarter@ufl.edu

Alexa Lamm, Ph.D., is an assistant professor in the Department of Agricultural Education and Communication and Associate Director of the UF/IFAS Center for Public Issues Education at the University of Florida. alamm@ufl.edu

Angie Lindsey, Ph.D., is an assistant professor in the Department of Family, Youth, and Community Sciences at the University of Florida. ablindsey@ufl.edu 